\title{
Fang Dongmeijeva filozofija ustvarjalnega kozmosa ${ }^{1}$
}

\author{
Jana S. ROŠKER
}

\section{Izvleček}

Fang Dongmei (1899-1977) je eden osrednjih predstavnikov druge generacije modernega konfucijanstva, četudi se sam nikoli ni izrecno izrekel samo za konfucijanca, temveč je vselej poudarjal, da je po duši poleg tega tudi daoist in budist. Vsekakor je teoretski doprinos tega, na zahodu še vedno precej neznanega modernega filozofa k moderni kitajski filozofiji vreden podrobnejše obravnave. Pričujoči članek se osredotoča predvsem na analizo in interpretacijo ontoloških in epistemoloških vidikov njegove filozofije, pri čemer so v ospredju njegovi koncepti celostne harmonije, konfucijanskega moralnega sebstva, ustvarjalne ustvarjalnosti, enotnosti dejstev in vrednot, ter razuma in intuicije.

Ključne besede: Fang Dongmei, moderno konfucijanstvo, kitajska filozofija, ustvarjalnost, celostna harmonija

\begin{abstract}
Fang Dongmei (1899-1977) is one of the main representatives of the second generation of Modern Confucianism, though he never explicitly claimed to be only a Confucian, but stressed being - in his soul - also a Daoist and Buddhist. The theoretical contribution of this philosopher (who is still rather neglected in the West) to the development of modern Chinese philosophy is doubtlessly worth detailed research. The present article mainly deals with the analysis and interpretation of the ontological and epistemological aspects of his philosophy. It focuses upon the introduction of the following concepts, central to his philosophy: comprehensive harmony, Confucian moral self, creative creativity, unity of facts and values, as well as reason and intuition.
\end{abstract}

Keywords: Fang Dongmei, Modern Confucianism, Chinese philosophy, creativity, comprehensive harmony

\footnotetext{
${ }^{1}$ Avtorica se zahvaljuje tajvanski akademski fundaciji Chiang Ching-kuo za podporo v okviru raziskovalnega projekta Taiwanese Modern Confucianists and their Contribution to Asian Modernization Theories, katerega del je pričujoča študija.
} 


\section{Ali je Fang Dongmei moderni konfucijanec?}

Fang Dongmei (1899-1977) je večinoma predstavljen kot filozof druge generacije modernega konfucijanstva. Njegovo delo je v kontekstu moderne in sodobne konfucijanske filozofije vsekakor potrebno omeniti, četudi se on sam nikoli ni izrecno opredelil za pripadnika modernega konfucijanstva, saj je vseskozi poudarjal, da je po duši tako kot konfucijanec tudi daoist in budist (Bresciani 2001, 23). Zato nas ne preseneti dejstvo, da ta filozof ni bil zgolj učitelj osrednjih predstavnikov tretje generacije modernega konfucijanstva, temveč tudi učitelj enega najbolj znanih sodobnih raziskovalcev daoizma, Chen Guyinga (Chen 1998, 96).

Vendar velja pri tem vsekakor opozoriti na dejstvo, da izraz konfucianizem ( $r u$ xue) pogosto na splošno označuje tradicionalno kitajsko miselnost; četudi so se neo-konfucijanci dinastij Song in Ming (torej tisti filozofi, ki so ustvarili miselnost, katera tvori osnovo modernega konfucijanstva) od budizma, daoizma in sorodnih, bolj mističnih in manj racionalnih tradicij navzven vselej odločno distancirali (in jih pogosto definirali celo kot svoje idejne sovražnike), pa je eden največjih teoretskih premikov oziroma preobratov neo-konfucijanskih diskurzov prav $\mathrm{v}$ tem, da so pripadniki te struje uspeli v ogrodje klasičnega konfucijanstva integrirati vrsto pomembnih konceptov in metod iz budističnih in daoističnih filozofij ${ }^{2}$. Pravzaprav je bila prav ta integracija idej, ki so bile iz vidika klasične, ortodoksne konfucijanske doktrine videti »heretične«, nevarne in ne-pravilne (fei zheng), tista, ki je merodajno opredelila reformo takrat že zelo okostenele in formalizirane konfucijanske klasike. Prav budistični in daoistični impulzi so bili torej tisti, ki so v obdobju od 10. do 14. stoletja rešili konfucianizem pred propadom, in ki so iz klasične državotvorne doktrine (ponovno) naredili miselnost, ki si zasluži ime filozofija ${ }^{3}$. Poleg tega so se tudi mnogi drugi filozofi iz struje modernega

\footnotetext{
${ }^{2} \mathrm{Na}$ primer koncepta subjekta in objekta spoznanja (neng-suo), ki izvirata iz budistične epistemologije in katera so uporabljali tudi predstavniki najbolj racionalističnih filozofij znotraj Šole strukture (li xue). Celo Zhu Xi, osrednji predstavnik te šole, je v svojo filozofijo vključil vrsto daoističnih idej in postopkov (na primer idejo skrajnega pola ali taijija, koncept wuweija ali nedelovanja ipd.), medtem ko so teorije predstavnikov idealistične struje neokonfucijanske filozofije (Šola srčne zavesti, Xin xue) tako rekoč temeljile na budističnih in daoističnih onto-epistmeologijah.

${ }^{3}$ Težko je reči, do kakšne mere je pri tem šlo za zavestni proces, vendar je integracija (in $\mathrm{s}$ tem »razelektritev«) budizma in daoizma neokonfucijanskim filozofom zagotovo predstavljala izziv; formalizirana klasično konfucijanska doktrina je bila v 10. stoletju izpraznjena vsakršnih resničnih vsebin in izobraženci so jo morali obvladovati za to, da so uspešno opravljali državne izpite, ki so njim samim in njihovim klanom odpirali vrata do politične oblasti. Seveda takšna doktrina izobražencem ni mogla nuditi nikakršne duhovne in intelektualne zadovoljitve. V ta namen so se raje ukvarjali s študijem in raziskovanjem daoizma in budizma. To je bilo za konfucijanizem in s tem
} 
konfucijanstva $\mathrm{v}$ svojih poskusih sintetiziranja evro-ameriških in kitajskih miselnosti ter v postopkih aktualizacije kitajske filozofske tradicije precej izdatno ukvarjali z mnogimi tradicionalnimi diskurzi, ki ne sodijo v okvir konfucijanstva $\mathrm{v}$ ožjem pomenu besede ${ }^{4}$. In končno, tudi pri tem velja upoštevati razlike med izvornimi kitajskimi pojmi in njihovimi konotacijami, ki izvirajo iz prevodov teh pojmov v indoevropske jezike. Izraz »ru xue«, ki se v indoevropske jezike prevaja kot »konfucijanstvo« (vključno s pojmom »modernega konfucijanstva«) seveda avtomatsko vključuje konotacijo Konfucija (Kong fuzi, Kongzi) in izrecno napeljuje na misel, da gre pri tem za (bodisi izvorni, bodisi reformirani ali modernizirani) Konfucijev nauk. V bistvu pa izraz »ru xue (儒學)《 v kitajščini pomeni »nauk izobražencev«, kar pomeni da v nominalnem smislu apriorno ne izključuje nobenih elementov, ki so merodajno oblikovali zgodovino kitajske miselnosti. To, kar imajo torej skupnega tako konfucijanska, kot tudi daoistična filozofija ter sinizirani budizem, je torej tisto, kar $\mathrm{v}$ resnici opredeljuje tradicionalno kitajsko filozofijo in njene »nauke izobražencev $\ll^{5}$.

Četudi se torej Fang Dongmei sam nikoli ni izrecno uvrščal med filozofe Modernega konfucijanstva, temveč v prvi vrsti tudi kot naslednika tradicionalnih budističnih in daoističnih filozofij, ga lahko - kot trdi njegov pomemben interpret Li Chengyang, vsekakor štejemo kot predstavnika konfucijanske filozofije v širšem, bolj splošnem smislu:

Although he has been regarded as contemporary New-Confucian along with Mou Zongsan, Tang Junyi, and Liang Shuming, Fang's work stands beyond the Confucian tradition. Unlike Mou Zongsan, Fang did not regard Confucianism as the only legitimate philosophy and all others as heresies; he argued that Laozi's Daosim was the leading and most legitimate philosophical

pravzaprav za celotni ideološki sistem, na katerem so slonele tradicionalne državne inštitucije, precej ogrožujoče. V tem smislu je bila neokonfucijanska reforma nujno potrebna za ohranitev konfucijanstva kot osrednje socialne, etične in filozofske miselnosti Kitajske.

${ }^{4}$ Moderni konfucijanci se sicer zelo redko opirajo na daoizem, kar je po svoje razumljivo, saj ta struja v bistvu ni nastala samo zato, da ohrani kulturno identiteto, temveč tudi z namenom aktualizacije in »rešitve« inštitucionalnega ustroja kitajske družbe; anarhistični klasiki daoizma pa za takšne državotvorne namene seveda niso preveč primerni. Vendar se je vrsta pomembnih modernokonfucijanskih filozofov izdatno ukvarjala s študijem in integracijo budistične mislenosti $v$ svoje teorije. Naj v tem kontekstu omenimo samo dva najbolj znana moderna konfucijanca, namreč Xiong Shilija in Mou Zongsana.

${ }^{5}$ Pri specifičnih značilnostih tradicionalne kitajske filozofije, ki so torej značilne za vse struje antične in klasične kitajske miselnosti, moramo omeniti predvsem koncept transcendentne imanence (oziroma imanentne transcendence), binarno strukturirani holizem, ki deluje preko binarnih kategorij (npr. yin-yang, you-wu, ti-yong, ming-shi, itd), ter načelo komplementarnosti, ki predstavlja metodo interakcij med obema protipoloma znotraj le-teh. 
school during ancient times. Fang saw Confucianism, Daoism, Mohism and Buddhism as mutually interacting and integrating components of a holistic cultural process, rather than as several distinct schools of thought ${ }^{6}$. (Li 2002, 269)

Vendar so bile osrednje vsebinske, konceptualne in metodološke predpostavke lete, kot smo videli, v veliki meri integrirane v ogrodje neokonfucijanskih teorij, ki pa večinoma zopet predstavljajo idejno osnovo, iz katere je na prelomu 2. in 3 . tisočletja vzniknilo moderno konfucijanstvo. Vendar prav $\mathrm{v}$ tem kontekstu naletimo v povezavi s Fang Dongmeijevo klasifikacijo še na nadaljnji problem, kajti prav hitro lahko ugotovimo, da se ta moderni filozof ni distanciral zgolj od modernih konfucijancev, temveč tudi od njihove idejne osnove, torej od neokonfucijancev dinastij Song in Ming. Njegova kritika neokonfucianizma je temeljila na stališču, da so ti filozofi (zlasti seveda pripadniki Zhu Xijeve Šole strukture, Li xue 理學) kljub svojim načelnim zaslugam za ohranjanje klasične konfucijanske tradicije ter njenega holističnega svetovnega nazora pretirano poudarjali pomen mehanistične racionalnosti, kakršen prihaja do izraza $\mathrm{V}$ strukturni logiki koncepta $l i$ (理) (struktura, strukturni vzorec). S tem naj bi deformirali holistično tradicijo filozofije, $\mathrm{v}$ kateri sta pola racionalnosti ( $l i$ 理) in občutenja (qing 情) med seboj usklajena, kar pomeni, da se lahko ohranja harmonična enotnost dejstev, vrednot in sfere estetskega doživljanja. Zato - za razliko od večine ostalih filozofov modernega konfucijanstva - nanje ni gledal kot na pripadnike »resničnega« oziroma »pravilnega« konfucijanstva ${ }^{7}$.

Under Confucianism Fang includes Confucius, Mencius and Xunzi, while the Han Confucians he thinks were "lowly and unworthy of mention" and the Song Neo-Confucians were not authentic followers of Confucianism. (Bresciani 2001, 275)

\footnotetext{
${ }^{6}$ Fang je na vprašanja o tem, s katero filozofsko strujo se identificira, odgovarjal, da je po svoji družinski tradiciji konfucianec, po značaju daoist, po verski inspiraciji budist in po izobrazbi zahodnjak (Li 2002, 264).

${ }^{7}$ Tudi mnogi drugi teoretiki so dejansko mnenja, da so neokonfucijsanski filozofi z Zhu Xijem na čelu predstavljali preobrat v kitajski tradiciji, ki se je izrazil skozi zametke dualizma kartezianskega tipa (gl. npr. Forke 1934, 173). Tudi Feng Yaoming govori o novi paradigmi, ki naj bi jo vzpostavili neokonfucianci v primerjavi s klasičnimi teoretiki te struje; v svojem članku »Zhongguo ru xuede dianfan zhuanyi (Paradigmatski preobrat v kitajskem konfucijanstvu) « Feng dokazuje, da se je referenčni okvir, v katerem so teoretizirali neokonfucijanski filozofi, v tolikšni meri razlikoval od referenčnih okvirov klasičnega konfucijanstva, da pri njih ne moremo več govoriti niti zgolj o teoretskem, temveč o paradigmatskem preobratu, kar pomeni, da je šlo pri neokonfucijanski filozofiji za popolnoma druge in nove teorije konfucijanstva, ki po svojem bistvu s starejšimi niso več primerljive.
} 
Po drugi strani pa sodi Fang med pomembne in vplivne teoretike in filozofe, katerih delo predstavlja precejšen doprinos na področju teoretske refleksije procesov kitajske modernizacije in poskusov ustvarjalnega razreševanja izzivov zahodne filozofije, $\mathrm{s}$ katerimi je bil $\mathrm{v}$ obdobju realizacije teh procesov soočen tako on sam, kot tudi njegova domovina. Kljub vsemu je bil Fang Dongmei tudi eden tistih novodobnih kitajskih filozofov, ki so odgovore na najbolj pereča idejna vprašanja svoje dobe iskali $\mathrm{v}$ revitalizaciji lastne tradicije, pri čemer sicer - za razliko od večine modernih konfucijancev - ni izhajal iz elaboracij neokonfucijanskih diskurzov, temveč predvsem neposredno iz zapuščine klasičnega konfucijanstva, oplemenitenega $\mathrm{z}$ estetskimi in metafizičnimi idejami klasičnega daoizma in siniziranega budizma. Pri tem moram vsekakor poudariti, da izhajam iz širšega razumevanja izvornega kitajskega izraza $r u$ xue (konfucijanstvo, dobesedno: nauk izobražencev), ki zame ne pomeni zgolj Konfucijevega nauka, ampak pridobiva v svoji konotaciji kulturno dominantnega diskurza kitajske (in širše vzhodnoazijske) tradicije tudi pomen široke palete prevladujočih filozofskih teorij, ki so $\mathrm{v}$ krogotoku tisočletij skupaj oblikovale kitajsko idejno zgodovino. Poleg tega je Fang tudi daoistično filozofijo, v kateri je vsekakor najti tudi precej kritičnih, individualističnih in svobodnjaških elementov, vselej interpretiral v okviru svoje neo-konservativne ideologije, ki predstavlja eno bistvenih, tako rekoč paradigmatskih značilnosti modernega konfucijanstva.

Iz vseh teh razlogov menim, da lahko Fang Dongmeija prištevamo k struji modernega konfucijanstva, saj je tej idejni struji s svojimi doprinosi zapustil tudi neizbrisen pečat.

Poleg tega pa Fanga nekateri teoretiki raje umeščajo v prvo generacijo tega idejnega gibanja, saj je starejši od He Lina in je med drugim poučeval tudi Tang Junyija (Liu 2001, ii), medtem ko ga drugi (npr. Bresciani 2001) raje prištevajo k drugi. Ker je bil Fang Dongmei hkrati tudi sam učitelj dveh najvplivnejših še živečih predstavnikov tretje generacije ${ }^{8}$, in predvsem zato, ker je merodajno sooblikoval trende sodobne tajvanske filozofije, ki predstavlja enega osrednjih predmetov pričujoče raziskave, ga bom v kontekstu pričujoče razprave - ne glede na njegov pionirski doprinos $\mathrm{k}$ modernim vzhodnoazijskim filozofijam - tudi sama uvrstila v Brescianijevo kategorizacijo in ga štela med pripadnike 2. generacije modernega konfucijanstva.

\footnotetext{
${ }^{8}$ Cheng Zhongyinga in Liu Shuxiana
} 


\section{Življenje in delo}

Kategorizacija tega filozofa kot modernega konfucijanca je nekoliko problematična tudi zato, ker se tudi sam večinoma ni prišteval $\mathrm{k}$ tej struji. Podrobnejšo razlago o tem, zakaj ga sama uvrščam med filozofe tega gibanja, in tudi o tem, zakaj ga uvrščam $\mathrm{v}$ drugo, in ne v prvo generacijo (kamor bi po svojih letih, poziciji in doprinosu prav tako lahko sodil), sem navedla v svoji knjigi o modernem konfucijanstvu, Subjektova nova oblačila (2013).

To, kar ga loči od ostalih predstavnikov druge generacije, je namreč tudi dejstvo, da so bili vsi študentje Xiong Shilija, katerega mnogi označujejo kot največjega pionirja moderne konfucijanske prenove (prim. Yu 2001, 127). Kljub svoji vseskozi izraženi pripadnosti svojemu profesorju in velikemu pionirju modernega konfucijanstva pa se njihova dela od Xiongovih precej razlikujejo; četudi so svojemu učitelju ostali zvesti glede njegove osnovne usmeritve in temeljne metodologije, katero so od njega prejeli, pa so vsi trije Xiongovi študentje, njegov nauk vendarle bistveno modificirali in nadgradili - seveda vsak na svoj specifični način (Feng 1993, 227). Četudi Fang Dongmei nikoli ni bil neposredni učenec Xiong Shilija, pa lahko pri obeh teoretikih naletimo na kar nekaj podobnosti: tako sta, denimo, oba poudarjala pomen tradicionalne kitajske binarne kategorije substance ( $t i$ 體) in funkcije (yong 用) za opredelitev razmerja med sferama noumena in pojavnosti in oba sta se izdatno ukvarjala s poskusi razjasnitve razmerja med filozofijo in znanostjo.

Nasploh lahko trdimo, da si je Fang v največji meri prizadeval za revitalizacijo svoje kulturne identitete v smislu »presaditve starih korenin ${ }^{9}$ « lastne tradicije, kajti $\mathrm{v}$ primerjavi z izzivi zahodnih kultur je samo $\mathrm{v}$ tem še videl možnost preživetja kulturne tradicije, iz katere je izhajal. Ta prenova »korenin« pa naj ne bi služila zgolj preživetju, temveč bi naj, v kolikor bi bila izpeljana dovolj vestno in natančno, zagotovila tudi aktivno in inovativno vlogo modernega konfucijanstva oziroma posodobljene kitajske miselnosti v mednarodnem dialogu modernih družb (Feng 1993, 227).

Fang, ki je v angleškem jeziku znan tudi pod imenom Thomé H. Fang, je bil rojen v družini znanih izobražencev osrednje kitajske province Anhui. Zato je bilo samoumevno, da se je od mladih nog podrobno seznanjal s kitajskimi klasiki. Po končani srednji šoli se je vpisal na Univerzo Jinling v Nanjingu, kjer je bil zelo

\footnotetext{
9 “重整舊學的根基” (Feng 1993, 227).
} 
aktiven v študentskem gibanju. Leta 1919 se je v Nanjingu udeležil tudi študentskih demonstracij, ki so bile organizirane v sklopu četrtomajske kulturne prenove. V letu 1920 je na isti univerzi spoznal ameriškega filozofa Deweya ${ }^{10}$, ki je v sklopu serije gostujočih predavanj na Kitajskem nastopil tudi v Nanjingu. Ta je v njem vzbudil veliko zanimanje za zahodno filozofijo, tako da je po diplomi odšel v ZDA, kjer je na Univerzi Wisconsin v enem letu magistriral, v naslednjih dveh letih pa dosegel doktorat na Državni univerzi v Ohiu.

Po vrnitvi na Kitajsko je poučeval filozofijo na več univerzah, med drugim na Univerzi Wuchang (Wuchang daxue 武昌大學), na Jugovzhodni Univerzi v Nanjingu (Nanjing Dongnan daxue 南京東南大學) na Politični univerzi (Zhengzhi daxue 政治大學) in nekaj časa tudi na Pekinški univerzi (Beijing daxue 北京大學). V času, ko je poučeval v Nanjingu, so morali univerzo zaradi japonske invazije preseliti v Chongqing v jugozahodni provinci Sečuan (Bresciani 2001, 272). Zaradi težavnosti vojnih razmer in iz želje po tem, da bi v teh kriznih, negotovih časih našel vsaj varno notranje domovanje $\mathrm{v}$ tradicionalni kitajski kulturi, se je v tem obdobju pričel ponovno ukvarjati s klasično kitajsko filozofijo (Bresciani 2001, 272). Že v letu 1948 se je odselil na Tajvan, saj so ga tega leta povabili v službo na Državni Tajvanski univerzi (Guoli Taiwan daxue 國立台灣 大學), na kateri je vse do svoje upokojitve predaval filozofijo.

Večina njegovih najpomembnejših filozofskih razprav $\mathrm{v}$ kitajščini je objavljena v 12 zvezkih z naslovom Zbrana dela Fang Dongmeija (Fang Dongmei quan ji), ki so izšli leta 2004. Med najpomembnejša med njimi štejejo Znanost, filozofija in človeško življenje (Kexue, zhexue yu rensheng, 1936), Pregled filozofije življenja antičnih kitajskih filozofov (Zhongguo xian zhe rensheng zhexue gaiyao, 1937), Tri vrste filozofske modrosti (Zhexue san hui) in Ideal življenja in kulturni tipi (Shenghuo lixiang yu wenhua leixing). Pod imenom Thomé H. Fang je napisal tudi vrsto knjig v angleščini, denimo The Chinese View of Life: the Philosophy of Comprehensive Harmony, Creativity in Man and Nature, Chinese Philosophy: Its Spirit and its Development, itd.

Fang je v svojem teoretskem delu združeval obsežna znanja s področij antične, srednjeveške in sodobne zahodne filozofije na eni, in širokega spektra tradicionalne, zlasti konfucijanske, daoistične in budistične kitajske filozofije na

\footnotetext{
${ }^{10}$ Pragmatična filzofija John Deweya (1859-1952) je imela v tistem času izjemno velik vpliv na mlade kitajske izobražence. Med drugim sta pri njem na kolumbijski univerzi doktorirala tudi Hu Shi (1891-1962) in Feng Youlan (1895-1990).
} 
drugi strani. Poleg tega je v njegovih delih opazen tudi vpliv indijske filozofije. Od modernih zahodnih filozofov ga je najbolj navduševal Nietzsche, ki naj bi po mnenju nekaterih interpretov tudi močno vplival na Fangov lastni teoretski razvoj (Bunnin 1996, 224). V vrsti svojih del se je primerjave $\mathrm{z}$ indijsko in evropsko filozofijo posluževal zato, ker je preko takšnih primerjav lažje definiral posebnosti tradicionalne kitajske filozofije ${ }^{11}$. Ena takšnih je zanj tudi temeljno izhodišče kitajske klasike, ki naj bi videla in razlagala svet ter bivanje izhajajoč iz epistemoloških temeljev, ki v prvi vrsti niso bili osnovani na matematičnih in proto-znanstvenih, temveč prej na estetskih paradigmah (Fang 1957, 195-235). Kljub temu je njegovo videnje ontologije tesno povezano $\mathrm{z}$ racionalno strukturo kozmosa, kakršna izhaja iz temeljnega starokitajskega klasika Knjiga premen (Yi jing 易經). Tudi Fang je namreč opisal proces kozmične premene (nenehne ustvarjalne ustvarjalnosti bivanja) kot izraz racionalnosti, ki temelji na in hkrati zaobjema do potankosti razčlenjeni sistem »logike stvarstva« (Fang 1981, 83-118).

\section{Koncepta ustvarjalne ustvarjalnosti ter celostne harmonije}

V središču Fangove filozofije je koncept življenja oziroma živega, živečega (sheng). Po Fangovem mnenju so vse struje tradicionalne kitajske miselnosti izhajale iz kozmologije, ki jo opredeljuje vse-prevevajoči gon po življenju, po preživetju, vitalni impulz, ki nenehno ustvarja in poustvarja vse, kar obstaja (Fang 1957, 73). Koncept shengsheng, ki se pogosto pojavlja v kozmologiji Knjige premen, interpretira kot koncept ustvarjalne ustvarjalnosti, ki naj bi simbolizirala tovrstno vitalnost življenja.

The universe is a living entity that cannot be reduced to mere inertial physical stuff. This living universe is full of energy, and everything in it is somehow connected to the living process that penetrates the entire realm. This view may be called a life-ontology." For Fang, it is more than a "Gaia hypothesis"; it is reality. In his regard, the influence on Fang of Western philosophers such as Hegel, Bergson, and Whitehead is evident. (Li 2002, 265)

Drugi osrednji koncept Fangove filozofije je ideja celostne harmonije, ki naj bi bila značilna za tradicionalno kitajsko dojemanje sveta. V njem vesoljstvo kot tako vselej teži k ravnovesju in usklajenosti vseh posamičnih delcev in entitet svojega

\footnotetext{
${ }^{11} \mathrm{~V}$ svoji knjigi Tri vrste filozofske modrosti (Zhexue san hui) je izhajal iz kontrastivne primerjave med starogrško, moderno evropsko in tradicionalno kitajsko filozofijo.
} 
sistema. Le-ta je v materialnem pogledu prazen ${ }^{12}$ in se izraža zgolj skozi bogastvo in pronicljivost svojega duha.

In Fang's reading of the history of Chinese philosophy, he saw more the harmonious interplay of various schools of thought than conflict. It may be argued that Fang was too idealistic and romantic in his reading of the harmonious interplay of these philosophies, but for him, if harmony was not a reality, it was at least the ideal for the Chinese. ( $\mathrm{Li} \mathrm{2002,266)}$

Ta vera $\mathrm{v}$ harmonijo in $\mathrm{v}$ usklajeno delovanje sveta se seveda odraža tudi $\mathrm{v}$ njegovem pojmovanju morale oziroma moralne filozofije. Ker je kozmična tendenca $\mathrm{k}$ vzpostavljanju in ohranjanju ravnovesja skozi koncept shengsheng (ustvarjalne ustvarjalnosti) vseobsežna in neomejena, nima zgolj ontoloških, temveč hkrati tudi epistemološke razsežnosti. To pomeni, da v Fangovi filozofiji ni prostora za ločevanje med dejstvi in vrednotami. Kozmos je oplemeniten z dobroto, ki ne izhaja zgolj iz pragmatičnih postulatov skupnega medčloveškega bivanja, temveč je apriorni del njegove esencialne strukture, ki se odraža tudi v sferi čiste estetike (Li 2002, 19). Zanj je moralnost esenca življenja in hkrati konkretno utelešenje najglobljih človeških vrednot.

Vsako človeško bitje zato samo po sebi ne teži zgolj po preživetju, temveč v enaki meri po osmišljanju svojega bivanja. Ta estetska plat kulture in umetnosti je izraz človeške ustvarjalnosti, ki je vselej usmerjena $\mathrm{k}$ izpopolnjevanju pomanjkljivosti sveta, v katerega smo vrženi; dao pri tem predstavlja pot, ki vodi $\mathrm{k}$ popolnosti in hkrati pot, na kateri se dejstva in vrednote združujejo v organsko strukturirani harmoniji.

Therefore, in Fang's view, truth, goodness, and beauty are a unity; qing (the emotive) and $l i$ (the rational) are connected. Indeed, Fang's moral philosophy is established on his "life-ontology"... This philosophy is also called "valuecentered-ontology".

His "life-ontology" and "value-centered-ontology" are directly connected because, for him, life is value and both life and value are rooted in the dao. The dao, as the all-encompassing and all-pervading unity, is the ultimate source of life, value, and harmony. (Li 2002, 268)

\footnotetext{
${ }^{12}$ Praznina, ki je v tukaj uporabljenem smislu odstotnost substance, je koncept, ki je znan predvsem iz budizma in daoističnih klasikov; a četudi se je klasični konfucianizem v glavnem osredotočal na pragmatiko tukaj-in-zdajšnjega trenutka, na politično filozofijo in na pragmatično etiko, pa je koncept praznine $\mathrm{v}$ tem kontekstu že kmalu po koncu dinastije Han - predvsem preko vpliva zgodnjega budizma - prodrl tudi v konfucijanske diskurze. Kasneje je predstavljal enega osrednjih konceptov idealistične struje neo-konfucijanstva.
} 
V svojem prej omenjenem delu Zhexue san hui, 哲學三慧 (Tri vrste filozofske modrosti) je filozofijo definiral kot sintezo med racionalno strukturo mišljenja (li) in čustvi (qing), 理 - 情. Po Knjigi premen naj bi oboje izhajalo iz skrajnega pola (tai ji 太極), ki je onto-epistemološki, neopisljivi in neizrekljivi praizvor vsakršnega bivanja. Zato qing in li nista zgolj osnova vsakršnega filozofiranja, temveč tudi temelj bivanja kot takega. Feng oba elementa vidi kot binarno kategorijo, saj je njun vzajemni odnos korelativen in komplementaren. Njuna vzajemna interakcija je proces, ki preveva tako dejstva, kot tudi možnosti, in iz katerega filozofija črpa svoj izvor, svoje resnice in svojo skrivnostnost (Li 2002, 264).

\section{Apriorna dobrota človeka ter enotnost dejstev in vrednot}

V svojih interpretacijah tradicionalne kitajske filozofije je izhajal iz holističnega vidika, po katerem tvori človek enoto s prostorom in časom. $\mathrm{V}$ ospredju njegovih interpretacij je tudi tradicionalna enotnost vrednot, ki skozi nenehno ustvarjanje vključuje tako delovanja narave oziroma neba (tian 天), kot tudi človeka. Skozi to enotnost vrednot je Fang poskušal vzpostaviti tudi sistem enote ontologije in antropologije (Bresciani 2001). Kljub svojemu deklarativno širokemu izhodišču, ki je vključeval večino vplivnih diskurzov starokitajske in klasične kitajske filozofije, je prav v tej osrednji točki dokazal, da kljub vsemu izhaja iz klasičnega mencijanskega stališča o štirih prirojenih zametkih (si duan 四端) človeške dobrote, s čimer je kljub svoji (prav tako jasno izraženi) distanci do neokonfucianizma dinastij Song in Ming dokazal, da sledi točno tisti tradiciji, ki je oblikovala temelje te predmoderne konfucijanske prenove ${ }^{13}$.

The universe is a place to live in, and not a place to escape from, because it is a realm of value. Similarly, human nature is something to rely upon, and not something to dispense with, because it has been proved to be not sinful but innocent. (Fang 1980b, 99)

Vendar se od te linije razmeji s tem, da vselej znova poudarja, da je prirojena dobrota človeka ena skupnih značilnost vseh tradicionalnih kitajskih filozofov (Fang 1980b, 87-115) in poskuša prepričati bralce, da je bil celo Xunzi, ki se je

\footnotetext{
${ }^{13}$ Pri tem gre za tradicijo linije Konfucija in Mencija (Kong-Meng), torej za tradicijo, ki je kot resničnega naslednika izvornega konfucijanstva kanonizirala Mencija (za razliko od prve prenove tega nauka v sklopu Dong Zhongshujevih reform za časadinastije Han, v katerih je to mesto zavzel Xunzi).
} 
ravno glede tega vprašanja v zgodovino zapisal kot osrednji Mencijev nasprotnik, $\mathrm{v}$ bistvu istega mnenja, samo da je pri tem zamenjal vlogi narave in čustev:

We can find no valid reasons for the theory of evil nature. Even Hsüntze ${ }^{14}$ held the belief that "human nature is a natural achievement" or "human nature attains itslef after the pattern of constant nature..." The reason why Hsüntze considered human nature to be evil is that he confused it with emotion which, logically speaking, is of a lower type than original nature. The evilness of human nature is here inferred, a posteriori, from the evilness of emotion. Here Hsüntze commits a fallacy of the confusion of logical types. (Fang 1980b, 109)

V svojem primerjalnem vidiku in v prizadevanju za harmonično sintezo njegovega lastnega dela, se je Fang precej ukvarjal tudi s skupnimi točkami vseh treh osrednjih struj klasične kitajske filozofije. Ugotovil je, da jih povezuje koncept dao, ki ga sicer vsaka od njih obravnava iz nekoliko drugačnega vidika in na nekoliko drugačen način, in vendar gre pri vseh teh vidikih za opisovanje koncepta holistične uravnovešenosti in težnje $\mathrm{k}$ popolnosti. Ker je dao možen samo v kontekstih holističnega nazora, lahko odraža tako metodo imanentne transcendence, kot tudi enotnost dejstev in vrednot, absolutnosti in relativnosti.

\section{Znanost in demokracija, zahodni subjekt in konfucijansko sebstvo}

Fang Dongmei je zagovarjal načelo strpnosti, ki je zanj pomembna predpostavka demokratične družbe; v tem kontekstu je kritiziral tudi Mencija, ker naj bi ta preostro napadal moistično šolo, ki je kitajski idejni tradiciji nudila mnogo dragocenih doprinosov, med katere sodijo tudi njeni zametki znanosti (Fang 1992, 437). Princip ustvarjalne ustvarjalnosti, ki je v ospredju Fangovih teorij (Fang 1980a, 36), predstavlja zanj tudi jedro možnega razvoja znanosti in demokracije:

Furthermore, man's mission of cultural creations in different realms of art, literature, science, religion, and social institutions is being carried on so as to bring any imperfections that there may be in Nature and Man into ideal perfection (Fang 1980b, 11).

Tako kot ostali predstavniki modernega konfucijanstva, tudi Fang priznava, da kitajska idejna tradicija ni izpostavila dovolj osnov za razvoj znanosti, kateri načelno ne nasprotuje: "Science has not gained its predominant position in Chinese culture as it should have done« (Fang 1980b, 19).

\footnotetext{
${ }^{14}$ T.j. Xunzi, Fang je v svojih angleških delih uporabljal transkripcijo Wade-Giles.
} 
To dejstvo opravičuje v luči holistične narave kitajske idejne tradicije:

The reason for it is not far to seek. The Chinese can easily realize its importance as a form of knowledge. But in the West, several meanings have been attached to it. The Greeks took it to be a rational explanation of the inherent order of things in the universe to which human beings are harmoniously related. We have science in China, if science means just this.... But even here there is a difficulty. The Greek thinkers conceived things under the form of the specious present as eternity. The passage of Nature was explained only quantitatively as a mechanical process of combination and separation. We Chinese have seen things differently. Nature is permeated with life. Nature is charged with value. Any process of change in Nature must be qualitative and gives rise to novelties; Nature and Man are congenial with each other. In the achievement of culture, nature is a help, not an encumbrance (Fang 1980b, 19).

Tako konec koncev pride do zaključka, da znanost v trenutno obstoječih oblikah ne predstavlja nečesa, za kar bi si bilo potrebno posebej prizadevati. Ker namreč ta tip znanosti, ki korenini v tradiciji kartezijanskih dualizmov, človeka obravnava zgolj kot mehanističen element družbe, ki je ločena od narave, je narava (prevladujočega zahodnega tipa) znanosti zanj v bistvu dogmatična in kot taka torej ne more predstavljati predpogoja resnične demokracije, temveč kvečjemu oviro na poti $\mathrm{k}$ njej:

Modern Europeans have thought of science as a systematic study of Nature, organic as well as inorganic, apart from man... The very distinction between primary and secondary qualities tends to rule man out of real Nature. Science seeks pure objectivity and Man, as explained by modern psychology and epistemology up to the middle of the nineteenth century, is essentially subjectivity. In this realm of pure objectivity, science tries by all means to analyze what is abstract, to grasp what is mainly quantitative, and to ascertain what is exact, with a view of reducing all things it investigates into formulas of identity. And it is scarcely possible to treat man in such a way (Fang 1980b, 19).

Za Fang Dongmeija torej kitajska tradicija ni vsebovala zgolj zametkov, ki bi lahko privedli do kakršnega koli modernega demokratičnega sistema, temveč predpostavke, ki naj bi omogočali razvoj človeške družbe k resnični demokraciji, katera je (vsled svojega upoštevanja človekove organske povezanosti z naravo) veliko bolj razumna in utemeljena, kot vse obstoječe demokracije zahodnega tipa. To Fangovo stališče je povezano z njegovim splošnim prepričanjem o tem, da lahko kitajska filozofija svetu nudi izhod iz idejne krize, v kateri so se zaradi svoje 
dualistične, racionalistične in scientistične naravnanosti znašle (trenutno dominantne) zahodne filozofije in empirične znanosti.

To se je odrazilo tudi v njegovem razumevanju individualizma. Fang Dongmei v svojih idealiziranih interpretacijah kitajske kulture izhaja iz holističnega nazora, $\mathrm{v}$ katerem je noumenon enak phenomenonu, $\mathrm{v}$ katerem oba $\mathrm{v}$ enaki meri preveva sfera vrednot, in v katerem zato ni prostora za kakršne koli delitve znotraj sebstva. Fang ne priznava koncepta subjekta in zato ne vidi ločnice med njegovimi transcendentnimi in empiričnimi dejavniki, ampak ostaja zvest svojemu metafizičnemu pragmatizmu:

The universe is a place to live in, and not a place to escape from, because it is a realm of value. Similarly, human nature is something to rely upon, and not something to dispense with, because it has been proved to be not sinful but innocent. The entire unvierse is, as we have said, a coalescence of matter and spirit, namely, a transformed realm wherein matter and spirit tend to take a higher form of perfection which may be called exalted life. Universal life permeates the universe, penetrating itself into everything. As it goes on in continuous creation, it increases the values of that which is already valuable to that which is quite indifferent. Our aim of life consists in the realization of supreme Good which, however, is not to be attached merely to the other world. So from the very beginning we have to learn what is most precious in life through the very living of it in this actual world (Fang 1957, 60-61).

Vendar je lahko pojem individuuma neločljivo povezan tudi s pojmoma enkratnosti in neponovljivosti, ki ne vsebujeta nikakršnih konotacij članstva $\mathrm{v}$ kakršnem koli razredu, niti pripadnosti kateri koli vrsti. Enakost se tukaj vzpostavlja na osnovi principa paritete. Prav ta pomen »enkratne individualnosti« je tisti, ki nam lahko pomaga dojeti tradicionalni konfucijanski koncept sebstva. Tudi moderni konfucijanci poudarjajo, da je enkratnost, katera tvori njegovo osnovo, že sama po sebi vrednota:

Dao je vse-prevevajoč in v sebi združuje vse $\mathrm{v}$ enoto. Zato pravimo, da je véliki dao brezmejen. A znotraj njega so tudi posamičnosti, ki so specifične. Enkratnost teh posamičnih enot moramo sprejeti kot resnično. Vsaka posamičnost, ki se udejani, nosi $\mathrm{v}$ sebi tendenco vrednosti. Zato njenega pomena nikakor ne moremo zanikati ${ }^{15}$. (Fang 2004, 259)

\footnotetext{
${ }^{15}$ 道通為一, 是謂大道無線, 其中各體化之有限分殊觀點, 就其獨特性而論, 必須接受 之, 視為真實. 蓋任何個體實現, 皆各表價值方向, 故於其重要性不容否認.
} 
To je sebstvo, katerega enkratna individualnost se konstituira skozi kakovost njegovih raznovrstnih odnosov z zunanjim svetom.

A person becomes recognized, distinguished, or renowned by virtue of communal deference to the quality of one's character. Much of the effort in understanding the traditional Confucian conception of self has to do with clarifying this distinction... While the definition of self as irreducibly social certainly precludes autonomous individuality ${ }^{16}$, it does not rule out the second, less familiar notion of uniqueness expressed in terms of my roles and my relationships (Fang 2004, 259).

Kadar torej raziskujemo stališča modernih konfucijancev glede razmerja med transcendentnim in empiričnim sebstvom, ne smemo pozabiti, da je to razmerje (za razliko od dualističnega modela) v kitajski tradiciji, iz katere izhajajo, vselej apriorno umeščeno v tovrstni kontekst različnih struktur socialnega omrežja, ki je opredeljevalo identiteto posameznika.

Za Fang Dongmeija je ideja subjekta nekaj, kar človeka v bistvu oddaljuje od njegove človeškosti; to idejo vidi kot tesno povezano $\mathrm{z}$ razvojem moderne evropske znanosti v smislu sistematičnega raziskovanja (organske in anorganske) »narave« kot nečesa, kar je popolnoma ločeno od človeka.

From the very beginning there has been the tendency to emphasize deanthropomorphism. The very distinction between primary and secondary qualities tend to rule man out of real nature. Science seeks after pure objectivity and man, as explained by modern psychology and epistemology up to the middle of the nineteenth century, is essentially subjectivity (Fang 1957, 31)

Subjektivnost je torej videna kot nekaj, kar je $\mathrm{v}$ diametralnem nasprotju in protislovju $\mathrm{s}$ čisto objektivnostjo, znotraj katere naj bi znanost poskušala analizirati abstraktnost, evidentirati bivajoče v skladu s kvantitativnimi kriteriji in raznovrstnost pojavnosti reducirati na formule različnih identitet (Fang 1957, 32). Po svojem bistvu je zanj ta metoda enaka zanikanju človeka kot naravnega bitja, umeščenega $\mathrm{v}$ vzajemno prepletene organske strukture, ki sestavljajo vesoljstvo, čas in prostor.

In kar se tiče neskončnega števila človeških individualnih posebnosti, si vse te prirojene različnosti prizadevajo za to, da bi našle pot do harmonične

\footnotetext{
${ }^{16}$ Gl. prejšnjo opombo. Za razliko od Halla in Amesa bi tukaj namesto dihotomije »avtonomnega« vs. »enkratnega individuuma predlagala razlikovanje med »izoliranim« in »relacijskim« posameznikom.
} 
združitve v celoto neskončnega bogastva mnogoterosti znotraj vélikega daota, zakaj ko so znotraj njega, se ne morejo izgubiti v neskončnem prostoru praznine, niti $\mathrm{v}$ banalni samoti oddvojenosti, ne $\mathrm{v}$ nekakšni navidezni enakopravnosti ${ }^{17}$ (Fang 2004, 261).

Fang ne govori o subjektu, temveč kvečjemu o »subjektnem duhu« (zhuti jingshen 主體精神) (prim. Fang in Li 1985, 892), ki predstavlja neločljivi del ontologizacije »življenja«. V njegovi filozofiji se »objektivni svet« (keguan shijie 客觀世界) nujno združuje s »subjektnim duhom človeštva« (zhutide renlei jingshen) in to, kar oboje povezuje, je »nenehna organska ustvarjalnost jasnega duha ${ }^{18}$ "(shengming shenshenbuxide chuanzaoli) (Fang in Li 1995, III/904).

Po Fangovem mnenju se subjektni duh v tej sferi življenja najprej - preko objektivizacije - transformira $\mathrm{v}$ objektni duh, nato pa se ta ontologizira $\mathrm{v}$ transcendentnega duha ${ }^{19}$ (Fang in Li 1995, III/892-93). Po Fangovem mnenju je samo-uresničevanje posameznika edina metoda, ki mu omogoča ohranitev njegove organske povezanosti z vsem, kar obstaja in njegovo vključitev v zgoraj omenjeni proces nenehne organske ustvarjalnosti, ki je osnova življenja:

Thus, between the two paths of self-abnegation and self-approbation, the Chinese traditions emphasize a third way, that is, self-development and selfrealization (Fang 1981, 23-28).

Ta proces samo-razvoja in samo-uresničitve je seveda tesno povezan $\mathrm{z}$ notranjo duhovno kultivacijo posameznika.

We think of the human individual in terms of observed actualities and idealized possibilities. From actuality to possibility, there is an elaborate process of self-development, an arduous task of self-(cultivation) as well as a full range of self-realization. (Fang 1981, 27)

Zavest poenotenja posameznika $\mathrm{z}$ vsem bivajočim, ki je rezultat tega procesa samo-uresničitve, pa ni metafizična $\mathrm{v}$ smislu abstraktne oddvojitve od praktične dejanskosti. Konkretne vrednote človeškega življenja ne sodijo v sfero idealizirane domišljije, ne $\mathrm{v}$ domeno transcendentnega nebeškega raja. $\mathrm{V}$ tem primeru namreč

${ }^{17}$ 乃在於為人類萬般個性之, 天生差別某致其調和之道, 而合之亦大道之無顯豐富性, 並非化除於漫無的準, 意義貧泛之單一性, 或表面上的評等性也.

18 顯然, 上述的《哲學建築《企求的是》客觀世界《與》主體的人類精神《貫通, 而作為兩者貫通 的連續點或曰相關點即》生命生生不息的創造力《.

19 方東美走完了將《生命《本體化的思想歷程: 先將《生命《由主體精神對象化為客體精神, 然後 將客體精神本體化為超越精神. 
ne bi imele nikakršne realne vrednosti, saj jih človek v dejanskem svetu ne bi mogel uresničiti. Po drugi strani pa tudi ne morejo ostati zaklenjene v narcisoidno notranjost posameznika, kajti $\mathrm{v}$ tem primeru gre za subjektivni egocentrizem, ki ni v nikakršno korist človeški skupnosti. Edina realna sfera, v kateri lahko človek uresniči in izpopolni te vrednote ter preseže ozko omejenost osebnih interesov, je država, katera Fangu predstavlja edino možno obliko razširjene eksistence, ki zagotavlja največjo možno srečo za največje možno število ljudi.

To obtain this objective in view, inasmuch as we are actual beings in this actual world chained to its limitations and imperfections, we have to overcome many difficulties that stand in our way through effort, courage, perseverance, and sagacity; to set ourselves free from self-bondage, for one thing, and from social constraint and enslavement, for another; and, in short, to transcend any imperfection that weighs us down either from within or from without. When all this has been done, we can escape above from the fatality below and behold the light of day in perfect freedom and happiness (Li 2002, 278).

\section{Razum in intuicija}

Za Fang Dongmeija je bil razum osnovan v racionalni strukturi $(l i)$ vesoljstva, ki pa je hkrati $\mathrm{s}$ to racionalnostjo opredeljena tudi $\mathrm{z}$ delovanjem občutenja (qing). Fang je izhajal iz predpostavke, po kateri gre pri obeh elementih za korelativno in komplementarno binarno kategorijo, katera izvira iz skrajnega pola (taiji) in tvori (znotraj onto-epistemološke celovitosti, ki je značilna za klasično kitajsko idejno tradicijo) tako osnovo filozofskega mišljenja, kot tudi temelj bivanja kot takega (Li 2002, 264). Medtem ko je »li« absolutni in najvišji izraz objektivnih pojavnosti, je »qing« zanj fundamentalna lastnost subjektivnosti. In ker Fang Dongmeijev koncept »življenja« v sebi združuje oba pojma, je popolnoma jasno, da nosi v sebi tudi pomen preseganja ločnice med subjektom in objektom ${ }^{20}$ (Fang in Li 1985, III/894). V svojem delu Tri vrste filozofske modrosti (Zhexue san hui) združi pojma »li« in »qing« tudi v enoten epistemološki koncept »občutenega razuma (qingli 情理)《, ki predstavlja v svoji združitvi občutja in racionalnosti fundamentalno in najprvobitnejšo srž oziroma osnovo spoznanja in predstavlja »seme modrosti« (zhihui chongzi 智慧種子) (Fang in Li 1985, III/894).

20 因為》理《屬於客體世界的終極意象, 》情《屬於主體世界的終極意象, 即然》生命《兼容》情, 理,《則它當然具有超越主客體世界的意義. 
Koncepta qing in li zato zanj predstavljata komplementarno celoto, v katerem sta oba dejavnika $v$ soodvisnem in korelativnem razmerju:

Qingli sodi med prvobitne simbolne podobe znotraj sistema filozofske terminologije. Qing nastane v povezavi z lijem in lijev obstoj je zopet odvisen od qinga. V svojem čudotvornem delovanju krožita eden krog drugega in sta eden drugemu izvorni razlog. Območje njunega skupnega obstoja lahko prepoznamo s pomočjo intuicije, a vendar ga je težko izraziti oziroma obrazložiti. ${ }^{21}$ (Fang 2007, 2)

Četudi vključuje qingli tako razum kot tudi občutja, ga je torej možno spoznati samo intuitivno, in ne $\mathrm{z}$ racionalno ali analitično metodo. Ta njegova epistemološka razsežnost se zato ne odraža zgolj v območju zaznavanja, temveč tudi v območju posredovanja, saj gre za koncept neizrazljivosti, ki presega pomenske distinkcije, kakršne opredeljujejo konkretni svet človeškega življenja:

Sfera qinglija je hkrati oddaljena in bližnja, globoka in površinska, odkrita in zakrita. Zunaj nje ni moč ničesar uzreti, in ustroj njene notranjosti lahko opredelimo s pomočjo sluha, vida in nege osebnosti. ${ }^{22}$ (Fang 2007, 2)

In vendar človek za svoj konkretni obstoj in za svoje konkretno življenje potrebuje oboje, tako qing, kot tudi $l i$ : „Človeško življenje je pogojeno s qingom in človeška eksistenca z lijem $^{23}$ «(Fang 2007, 2).

Razum sam po sebi (torej ločeno od občutja) zanj predstavlja tretjo raven razvoja osebnosti (od skupaj šestih); to je raven, ki ustreza človeškemu obvladovanju naravnega zunanjega sveta in se manifestira v kulturi znanosti. Fang sicer priznava, da je ta vidik človeškega razvoja pomemben, vendar hkrati opozarja na dejstvo, da mora človeštvo stremeti k še višjim sferam umetnosti (lepote), morale (dobrote) in popolnosti (harmonije), torej k sferam, do katerih človek brez intuitivnega (moralnega) znanja nima dostopa (Fang in Li 1995, III/904-6).

\footnotetext{
21 情理為哲學名言系統中之原始意象. 情緣理有, 理依情生, 妙如運環, 彼是相因, 其界繫統會可 以直觀, 難以詮表.

22 情理境界有遠近, 有深淺, 有精鹿, 有顯密, 出乎其外者末有窺測, 入乎其內者依聞, 思, 修的程 度而定其等差.

${ }^{23}$ 人類含情而得生, 契理乃得存.
} 


\section{Viri in literatura}

Bresciani, Umberto. 2001. Reinventing Confucianism - The New Confucian Movement. Taipei: Taipei Ricci Institute for Chinese Studies.

Bunnin, Nicholas. 1996. "Fang Dongmei (Thomé H. Fang).” V: Biographical Dictionary of Twentieth-Century Philosophers, urednili Stuart Brown, Diane Collinson in Robert Wikinson, 223-4. London \& New York: Routledge.

Chen Guying 陳鼓應. 1998. “Chen Guying pingjia dangdai xin ruxue 陳鼓應評當代新儒 學 (Chen Guying komentira sodobne moderne konfucijance).” V Taiwanzhi zhi zhexue geming - zhongjie sanzhong wenhua weiji yu ershi shiji zhi gaobie, avtor Wang Yingming, 95-98. Taibei: Shuxiang wenhua shiye.

Fang Dongmei 方東美. 1937. Zhongguo xian zhe rensheng zhexue jiyao 中國先哲人生哲 學概要 (Pregled filozofije življenja antičnih kitajskih filozofov). Taibei: Shangwu yin shu guan.

—. 1992. Shengming lixiang yu wenhua leixing - Fang Dongmei xin ruxue jiyao 生命理 想與文化類型: 方東美新儒學論輯要 (Ideal življenja in kulturni tipi: Fang Dongmeijeva osrednja dela o Modernem konfucijanstvu). Taibei: Zhongguo guangbo dianshi chuban she.

—. 2004. Fang Dongmei quan ji 方東美全集 (Zbrana dela Fang Dongmeija). Taibei: Liming wenhua chuban she.

—. 2007. Zhexue san hui 哲學三慧 (Tri vrste filozofske modrosti). Taibei: Sanmin shuju.

Fang Keli 方克立, in Jinquan Li 李錦全, ur. 1995. Xiandai xinrujia xue 'an 現代新儒家學 案 (Pregled akademskega dela modernih konfucijancev). Beijing: Zhongguo shehui kexue chuban she $3 \mathrm{zv}$.

Fang, Thomé H. 1957. The Chinese View of Life. Hong Kong: The Union Press.

—. 1980a. Creativity in Man and Nature: A Collection of Philosophical Essays. Taipei: Linking Publishing.

—. 1980b. The Chinese View of Life: The Philosophy of Comprehensive Harmony. Taipei: Linking Publishing.

—. 1981. Chinese Philosophy: Its Spirit and its Develpoment. Taipei: Linking Publishing.

Feng Yaoming 馮耀明. 1993. “Cong 'zhitong' dao ‘qucheng' - dangdai ruxue yu xiandaihua wenti 從 '直通' 到 '曲成' -- 當代新儒學與現代化問題 (Od »neposredne povezanosti« do »fleksibilnega nastanka« - Moderno konfucijanstvo in problem modernizacije)." Hanxue yanjiu 10(2): 227-51.

Forke, Alfred. 1934. Geschichte der mittelalterlichen chinesischen Philosophie (II). Hamburg: R. Oldenbourg Verlag.

Li, Chengyang. 2002. "Philosophy of Life, Creativity and Inclusiveness." V Contemporary Chinese Philosophy, uredila Chung-Ying Cheng in Nicholas Bunnin, 258-80. Oxford: Blackwell Publishers. 
Liu, Shuxian. 2001. "Introduction.” V Reinventing Confucianism - The New Confucian Movement, avtor Umberto Bresciani, i-ii . Taipei: Taipei Ricci Institute for Chinese Studies.

Rošker, Jana S. 2013. Subjektova nova oblačila - idejne osnove modernizacije v delih druge generacije modernega konfucijanstva. Ljubljana: Znanstvena založba Filozofske fakultete.

Yu, Jiyuan. 2001. “Xiong Shili’s Metaphyscs of Virtue.” V Contemporary Chinese Philosophy, uredila Chung-ying Cheng in Nicholas Bunnin, 127-46. Oxford: Blackwell Publishers.

\section{Summary}

Fang Dongmei (1899-1977) is an important and influential theoretician and philosopher, whose work represents a great contribution to the theoretical reflection on the Chinese modernization processes and an attempt to creatively solve the challenges of Western philosophy, faced by him and his homeland during the period when these processes were taking place. However, Fang Dongmei was one of those modern Chinese philosophers who sought answers to the most pressing philosophical questions in the revitalization of his tradition, at which he-in contrast to most modern Confucians - did not proceed from NeoConfucian discourses, but predominantly from classical Confucianism, enriched by the aesthetic and metaphysical ideas of classical Daoism and sinicized Buddhism. Regarding this issue, the present article proceeds from a broader understanding of the original Chinese expression ru xue (Confucianism, literary: the teachings of the educated). This concept is not considered merely as the teachings of Confucius as a person, but rather seen in the sense as understood in the dominant cultural discourse of Chinese (and broader eastern Asian) traditionnamely, as teachings that include a broader palette of prevailing philosophical theories which have co-formed Chinese philosophical history over the millennia. Fang always interpreted Daoism, which includes a lot of critical, individualistic and freethinking elements, within the frame of his neoconservative ideology that represents an essential, almost paradigmatic characteristic of modern Confucianism. In this framework, the article focuses upon the analysis and interpretation of some crucial elements which are typical for Fang Dongmei's work. 